\title{
ANALISIS PROSES KEPUTUSAN PEMBELIAN MINYAK GORENG SAWIT: STUDI KASUS PADA WARGA KOREA DI KABUPATEN BEKASI
}

\author{
Intan Pratama ${ }^{1^{*}}$, Ernah $^{1}$ \\ ${ }^{1}$ Departemen Sosial Ekonomi Pertanian Fakultas Pertanian, \\ Universitas Padjadjaran, Sumedang 45363, Indonesia
}

*E-mail: intan16023@mail.unpad.ac.id

\begin{abstract}
Abstrak
Proses keputusan pembelian konsumen merupakan suatu kemungkinan tindakan yang dapat terjadi dan berhubungan dengan berbagai hal seperti faktor budaya dan sosial. Penelitian ini bertujuan untuk menganalisis karakteristik konsumen, proses keputusan pembelian, serta hubungan faktor budaya dan sosial dengan proses keputusan pembelian minyak goreng sawit warga Korea. Penelitian menggunakan pendekatan kuantitatif dengan desain cross-sectional study. Sampel penelitian diambil melalui teknik snowball sampling berjumlah 42 responden. Pengumpulan data menggunakan instrumen penelitian berupa angket. Data dianalisis menggunakan analisis deskriptif dan korelasi rank spearman. Hasil penelitian menunjukkan mayoritas responden adalah ibu rumah tangga, sarjana, dan berpendapatan bulanan keluarga di atas Rp50.000.000,00. Frekuensi pembelian adalah sebulan sekali sejumlah 1-2 liter dan digunakan di atas seminggu sekali. Alasan utama pembelian adalah memperoleh produk berkualitas baik dengan harga terjangkau. Sumber informasi diperoleh dari toko dengan jenis informasi yang menjadi fokus utamanya adalah kualitas. Faktor utama yang dipertimbangkan saat membeli ialah kualitas. Konsumen merasa puas dan berniat membeli kembali minyak goreng sawit. Faktor budaya memiliki hubungan yang signifikan, positif, dan kuat dengan keputusan pembelian sementara faktor sosial memiliki hubungan yang signifikan, positif, dan rendah dengan keputusan pembelian. Hasil penelitian ini dapat digunakan sebagai informasi mengenai perilaku konsumen Korea khususnya dalam proses keputusan pembelian minyak goreng sawit.
\end{abstract}

Kata kunci: Bekasi, konsumen, Korea, minyak goreng sawit, pembelian

\section{Analysis of Purchase Decisions Process of Palm Cooking Oil among Korean in Bekasi District}

\begin{abstract}
Consumer purchase decisions process are actions that possibly occur and related to various factors such as cultural and social factors. This study aimed to analyze consumers' characteristic, purchase decision process, and relationship between cultural and social factors with palm cooking oil purchase decision process among Korean. This study used a quantitative approach with a cross-sectional study design. Research sample was taken using snowball sampling technique with a total of 42 respondents. Data were collected using research questionnaires and analyzed using descriptive analysis and Spearman's Rank Order Correlation. Results showed that, on average, consumers were a housewife, had a bachelor's degree with a monthly family income above 50.000.000 IDR. Buying frequency was once a month with a quantity of 1-2 liters and used more than once a week. The main reason to buy was to get a good quality of product with affordable price. Information source was obtained from stores with quality as the main focus. Main factor to consider when buying was quality. Consumers were satisfied and intended to repurchase palm cooking oil. Cultural factor had a significant, positive, strong correlation with purchase decisions. Social factor had significant, positive, low correlation. This study's results can be used as information regarding consumer behavior of Korean specially in palm cooking oil purchase decisions process.
\end{abstract}

Keywords: Bekasi, consumer, Korea, palm cooking oil, purchase

\section{PENDAHULUAN}

Memasuki era perdagangan bebas dengan derasnya arus globalisasi memberikan banyak dampak positif dan negatif bagi suatu negara. Globalisasi informasi telah mendorong negaranegara maju melalui World Trade Organization untuk menjadikan dunia sebagai pasar bebas 
dan menyebabkan batas-batas wilayah suatu negara semakin menyempit (borderless countries). Menyempitnya batas-batas tersebut telah mendorong manusia untuk melakukan perpindahan atau migrasi internasional yang tidak hanya terjadi antar wilayah dalam negara tetapi hingga melintasi batas teritorial antar negara bahkan antar benua (Haryono, 2017).

Kabupaten Bekasi merupakan salah satu wilayah perkotaan di Indonesia yang kerap menjadi tujuan migrasi internasional. Hal ini dapat dilihat dari jumlah imigran di kabupaten tersebut, yakni sebanyak 5.174 orang (Newsroom Diskominfosantik, 2020). Banyaknya Warga Negara Asing (WNA) menetap di Kabupaten Bekasi dikarenakan perkembangan industrinya yang pesat. Sebagai kawasan industri terbesar di Asia Tenggara, total investasi baik dari penanaman modal asing maupun dalam negeri Kabupaten Bekasi menempati peringkat pertama di Jawa Barat senilai 41 triliun rupiah. Menurut Sidjabat dan Runtuk (2019), terdapat 2.125 unit pabrik yang terletak pada kawasan-kawasan industri di pusat Kabupten Bekasi (Cikarang). Kawasan tersebut mampu memberikan kontribusi besar terhadap Penanaman Modal Asing Nasional $(34,46 \%)$ dan volume ekspor nasional (22$45 \%)$.

Salah satu negara yang mendominasi investasi di Kabupaten Bekasi ialah Korea Selatan. Selama dekade terakhir, kerja sama internasional Indonesia dan Korea Selatan khususnya dalam aspek ekonomi semakin meningkat setelah ditandatanganinya deklarasi bersama pembentukan kemitraan strategis pada Desember 2006 (Sormin \& Waluyo, 2018). Hal ini tentu menyebabkan banyaknya warga Korea yang menetap di Kabupaten Bekasi, yakni sebanyak 1.260 orang.

Hadirnya warga Korea dapat meningkatkan aktivitas perekonomian di Kabupaten Bekasi, khususnya dalam segi penjualan produk-produk lokal. Sebagai salah satu produk konsumsi, minyak goreng memiliki peluang yang baik secara ekonomi. Minyak goreng adalah satu dari sembilan bahan pokok esensial dan menjadi kebutuhan dapur utama dalam rumah tangga di Indonesia. Komoditas ini memiliki prospek yang cerah karena dapat dikonsumsi oleh seluruh lapisan sosial. Hal ini dapat dilihat juga melalui tingkat parsitipasi konsumsi minyak goreng yang tinggi $(87,98 \%)$, menempati peringkat 5 setelah beras $(96,82 \%)$, garam $(94,40 \%)$, bawang merah $(90,39 \%)$, dan gula pasir $(89,99 \%)$ serta lebih besar dari bawang putih dan telur ayam ras (Badan Pusat
Statistik, 2019). Di Indonesia, mayoritas merek minyak goreng lokal berbahan dasar kelapa sawit. Minyak kelapa sawit memiliki keunggulan-keunggulan tersendiri seperti relatif lebih tahan lama, tahan terhadap tekanan atau suhu tinggi, dan tidak cepat berubah menjadi tengik. Pada tahun 2010-2018, konsumsi rumah tangga minyak goreng sawit (MGS) secara garis besar meningkat dengan rata-rata peningkatan 3,47 persen per tahun (Kementerian Pertanian, 2019).

Akan tetapi, warga Korea diduga akan jarang mengonsumsi MGS. Selama ratusan tahun, teknik merebus dilakukan orang Korea untuk memasak sehingga makanan tradisional Korea biasanya tidak digoreng (Rencidiptya \& Hasanah, 2020). Sayuran dan makanan fermentasi cenderung lebih disukai dibandingkan makanan gorengan yang mengandung banyak minyak. Hal ini tentunya akan berpengaruh terhadap pembelian dan konsumsi MGS warga Korea.

Dalam menentukan pilihannya terhadap suatu produk, konsumen akan mengalami suatu rangkaian tertentu yang disebut juga proses keputusan pembelian. Keputusan pembelian konsumen merupakan suatu kemungkinankemungkinan tindakan yang dapat terjadi. Kemungkinan tersebut dapat berupa membeli atau tidak membeli, sedikit atau banyak, sekarang atau nanti, dan sebagainya. Beberapa pertanyaan yang diajukan dalam mempelajari proses tersebut bisa mengenai waktu pertama konsumen mengenal produk, keyakinan merek, keterlibatan dalam pembelian, proses seleksi hingga tingkat kepuasan pasca pembelian (Pasaribu et al. , 2019).

Proses keputusan konsumen dalam membeli akan ditentukan oleh berbagai hal. Faktor yang secara mendasar sangat memengaruhi konsumen dalam berperilaku ialah budaya. Sebagian besar perilaku manusia adalah hasil dari proses belajar. Individu yang sedang bertumbuh di tengah masyarakat akan memperoleh seperangkat nilai yang meliputi persepsi, keinginan, preferensi, dan perilaku dasar dari lingkungannya. Nilai-nilai ini tidak sama pada setiap wilayah dengan masingmasing budaya berbeda yang dimilikinya. Dengan demikian, tugas pemasar yang sangat penting ialah melihat pergeseran budaya tersebut untuk selalu menyediakan produkproduk yang sesuai dengan keinginan konsumen (Kotler \& Keller, 2016). Budaya memengaruhi pola pikir karena sifatnya yang menyeluruh, misalnya etnis tertentu 
menggemari rasa manis atau pedas sehingga menentukan keputusan pembelian makanannya (Budiman, 1997). Hasil penelitian Asprilia dan Hami (2021) menunjukkan, perbedaan pola nilai dominan antar budaya pada suku Sunda, Jawa, dan Minangkabau memperkuat teori bahwa budaya ialah faktor dasar yang memengaruhi keinginan, konsumsi, dan pemuasan kebutuhan konsumen. Keputusan pembelian konsumen berhubungan langsung dengan persepsi nilai budaya yang dianutnya.

Selain faktor budaya, proses keputusan pembelian juga sangat berkaitan dengan faktor sosial konsumen. Penelitian Yakup, Mucahit, dan Reyhan (2011) menemukan bahwa pada pengambilan keputusan konsumsi, budaya yang mencakup kepercayaan serta tradisi memiliki posisi penting, diikuti oleh faktor lingkungan seperti teman dan kelompok sosial. Kelompok-kelompok sosial dalam masyarakat cenderung menganut nilai, ketertarikan, dan perilaku yang serupa sehingga cenderung menyarankan kesukaan yang mereka miliki mengenai produk (Veterinawati, 2013). Manusia ialah makhluk sosial sehingga sebagian besar pola perilaku manusia berhubungan erat dengan orang-orang di sekitarnya (Ramya \& Ali, 2016). Maka, penting untuk memperhatikan faktor budaya dan sosial dalam mempelajari proses keputusan pembelian konsumen.

Hal yang perlu digarisbawahi adalah penelitian mengenai studi perilaku konsumen khususnya untuk produk minyak goreng biasanya hanya dilakukan pada subjek penelitian yang umum. Penelitian terdahulu hanya mengkaji konsumen pada tingkat individu, rumah tangga, atau bisnis. Masih jarang peneliti yang melakukan penelitian terhadap subjek dengan latar belakang budaya yang berbeda seperti konsumen WNA. Penelitian yang dilakukan oleh Bukhori dan Ekasari (2017), Nasution dan Syuhada (2018) serta Pinem dan Safrida (2018) menganalisis keputusan pembelian minyak goreng beserta faktor-faktor yang memengaruhinya pada kalangan ibu rumah tangga. Kartika dan Ningsih (2017) serta Sundari, Harisudin, dan Agustono (2018) menganalisis keputusan pembelian konsumen yang berada pada pasar swalayan dan tradisional. Anggraeni dan Adiwijaya (2017) meneliti keputusan pembelian pada konsumen umum, sementara Dwinada (2012) pada tingkat rumah tangga. Semua subjek penelitian terdahulu merupakan Warga Negara Indonesia (WNI). Belum ada penelitian yang meneliti
WNA yang tentunya memiliki nilai-nilai budaya berbeda dengan WNI. Padahal menurut Kotler dan Keller (2016), budaya ialah faktor dengan pengaruh terbesar terhadap keputusan pembelian konsumen. Penelitian di luar Indonesia terkait keputusan pembelian minyak goreng seperti Kumar (2014) juga hanya meneliti pada kalangan konsumen suatu kota di India sementara Topcu, Turhan, dan Uzundumlu (2010) pada konsumen tingkat provinsi di Turki.

Penelitian ini bertujuan untuk (1) menganalisis karakteristik konsumen; (2) menganalisis proses keputusan pembelian; dan (3) menganalisis hubungan faktor budaya dan sosial dengan keputusan pembelian minyak goreng sawit warga Korea di Kabupaten Bekasi. Peneliti juga menguji hipotesis bahwa terdapat hubungan yang signifikan antara faktor budaya dan sosial dengan keputusan pembelian.

\section{METODE}

Penelitian ini menggunakan desain penelitian cross-sectional study dengan pendekatan kuantitatif. Lokasi penelitian dipilih secara purposif yakni di Kabupaten Bekasi, Jawa Barat. Pertimbangan pemilihan lokasi tersebut dikarenakan banyaknya warga Korea di Kabupaten Bekasi. Pengumpulan data dilaksanakan pada bulan Juli hingga Agustus 2020.

Populasi penelitian ini adalah Rumah Tangga warga Korea yang mengonsumsi MGS dan berdomisili di Kabupaten Bekasi yang jumlahnya belum diketahui. Responden pada penelitian ini ialah anggota Rumah Tangga tersebut yang melakukan pembelian MGS. Teknik pengambilan sampel menggunakan snowball sampling dengan jumlah 42 orang. Pemilihan teknik tersebut mempertimbangkan populasi yang sulit diidentifikasi serta tidak lengkapnya data terkait anggota populasi. Sampel dijaring melalui koneksi dan komunitas warga Korea di Kabupaten Bekasi. Penentuan jumlah sampel mengacu pada pendapat Gay dan Diehl, untuk penelitian korelasional sampel minimal berjumlah 30 subjek (Jimanto, 2014).

Data diperoleh dari data primer dan sekunder. Data primer dikumpulkan dengan instrumen penelitian berupa angket yang disebarkan secara daring. Data dikumpulkan dengan menyebarkan tautan Google Form berisi kuesioner melalui media sosial Line dan KakaoTalk kepada responden serta melakukan 
wawancara daring. Responden dapat memilih satu dari tiga versi kuesioner yang tersedia, yakni kuesioner Bahasa Korea, Inggris, atau Indonesia.

Data primer dalam penelitian ini meliputi karakteristik konsumen (karakteristik demografi berupa jenis kelamin, usia, pendidikan, pekerjaan, pendapatan, besar rumah tangga, durasi menetap; preferensi; pembelian; penggunaan), proses keputusan pembelian (pengenalan kebutuhan, pencarian informasi, evaluasi alternatif, keputusan pembelian, perilaku pasca pembelian), faktor budaya, faktor sosial, dan proses keputusan pembelian.

Faktor budaya ialah kebiasaan, kepercayaan, dan nilai-nilai yang dianut konsumen. Faktor budaya dalam penelitian ini diukur melalui indikator kebiasaan, sikap, budaya serba cepat, etnosentrisme, dan nilai sosial. Pengukuran variabel berbentuk skala Likert dengan kategori jawaban dari skor 1 (sangat tidak setuju) sampai dengan 5 (sangat setuju). Kuesioner faktor budaya terdiri atas 5 pernyataan dengan nilai Cronbach's alpha 0,661.

Faktor sosial ialah lingkungan dan peran sosial konsumen, dalam penelitian ini diukur melalui indikator pendapat keluarga, pendapat teman, pengaruh keluarga, pengaruh teman, serta peran dan status. Pengukuran variabel berbentuk skala Likert dengan kategori jawaban dari skor 1 (sangat tidak setuju) sampai dengan 5 (sangat setuju). Kuesioner faktor sosial terdiri atas 5 pernyataan dengan nilai Cronbach's alpha 0,833 .

Proses keputusan pembelian ialah pembelian aktual MGS beserta proses sebelum dan sesudahnya, dalam penelitian ini diukur melalui indikator keputusan membeli, pencarian informasi, kemantapan membeli, sikap merekomendasikan, dan niat pembelian kembali. Pengukuran variabel berbentuk skala Likert dengan kategori jawaban dari skor 1 (sangat tidak setuju) sampai dengan 5 (sangat setuju). Kuesioner keputusan pembelian terdiri atas 5 pernyataan dengan nilai Cronbach's alpha 0,786 .

Data dianalisis menggunakan analisis deskriptif dan korelasi rank spearman. Analisis deskriptif digunakan untuk menguraikan karakteristik konsumen dan proses keputusan pembelian. Analisis korelasi rank spearman digunakan untuk menganalisis hubungan faktor budaya dan sosial dengan proses keputusan pembelian MGS warga Korea. Kriteria tingkat hubungan yang ditunjukkan dengan nilai koefisien korelasi antar variabel berkisar antara $\pm 0,00- \pm 1,00$. Interpretasi tingkat hubungan dibagi menjadi sangat rendah $(0,00-0,199)$, rendah $(0,20$ $0,399)$, sedang $(0,40-0,599)$, kuat $(0,60-0799)$, dan sangat kuat $(0,80-1,000)$.

\section{HASIL}

\section{Karakteristik Konsumen}

Jenis Kelamin. Penelitian ini melibatkan 42 warga Korea sebagai konsumen MGS di Kabupaten Bekasi. Hasil analisis menunjukkan proporsi responden wanita enam kali lipat $(85,7 \%)$ lebih banyak dibandingkan pria $(14,3 \%)$. Hal demikian terjadi dikarenakan secara umum konsumen minyak goreng ialah ibu-ibu rumah tangga. Wanita secara khususnya ibu rumah tangga lebih berperan dalam mengatur kebutuhan keluarga dan konsumsi rumah tangga. Maka, peran wanita dalam pengambilan keputusan pembelian MGS sangat besar.

Usia. Lebih dari setengah responden (69\%) terkategori paruh baya (36-50 tahun). Konsumen dengan usia demikan telah berpenghasilan mapan dan dapat membuat keputusan secara rasional dalam membeli produk. Konsumen dalam membeli MGS telah melalui pertimbangan tertentu dan memahami produk yang dibeli yakni sesuai dengan seleranya.

Pendidikan. Lebih dari setengah responden $(59,5 \%)$ berpendidikan sarjana. Tingginya persentase lulusan sarjana menunjukkan pendidikan konsumen yang tinggi. Konsumen dinilai baik dalam merespon informasi.

Pekerjaan. Pekerjaan responden didominasi oleh ibu rumah tangga (76,2\%). Ibu rumah tangga merupakan individu yang biasa mengambil keputusan pembelian kebutuhan rumah tangga yang salah satunya adalah pembelian minyak goreng.

Pendapatan. Mayoritas responden memiliki pendapatan keluarga di atas Rp50.000.000,00 per bulan $(76,2 \%)$. Hal ini disebabkan karena standar gaji WNA yang lebih tinggi dibandingkan WNI. Tingkat pendapatan akan memengaruhi konsumsi. Berdasarkan kurva Engel, seiring meningkatnya pendapatan, persentase pengeluaran konsumsi pangan juga akan berkurang dengan asumsi tingkat harga konstan. Dengan kata lain, pada konsumen berpendapatan tinggi seperti konsumen Korea, pengeluaran terhadap barang kebutuhan pokok (primer) seperti minyak goreng justru semakin 
kecil. Hal ini dikarenakan pengeluaran konsumen lebih besar pada barang mewah (sekunder dan tersier).

Besar Rumah Tangga. Kurang dari setengah responden $(47,6 \%)$ memiliki 4 anggota rumah tangga. Jumlah anggota rumah tangga yang paling besar ialah 6 orang sementara yang paling kecil ialah 2 anggota (Tabel 1).

Durasi Menetap. Sebagian besar responden telah menetap di Indonesia setidaknya 5 tahun, dengan rentang paling banyak terdapat pada 510 tahun $(57,1 \%)$. Durasi menetap yang paling banyak ialah 7 tahun sebanyak 8 orang (19\%). Durasi menetap paling lama ialah 35 tahun dan paling sebentar 1,5 tahun, masing-masing 1 orang $(2,4 \%)$.

Preferensi. Tabel 2 menunjukkan bahwa hampir seluruh responden (97,6\%) menggunakan MGS dan impor sementara hanya seorang yang menggunakan MGS saja. Hasil penelitian menunjukkan bahwa dua dari tiga responden $(66,7 \%)$ lebih sering menggunakan minyak goreng impor daripada MGS. Adapun beberapa merek impor yang digunakan responden ialah Bertolli (minyak zaitun), Beksul (minyak kedelai), Chung Jung One (minyak zaitun), Chung Jung One (minyak jagung), Chung Jung One (minyak biji anggur), dan Chung Jung One (minyak kedelai). Kebanyakan merek yang digunakan berasal dari negara Korea sendiri.

Lebih lanjut, hampir setengah responden $(47,6 \%)$ mengungkapkan bahwa alasan menggunakan minyak impor disebabkan karena untuk memasak hidangan tertentu. Responden menggunakan minyak goreng impor untuk menumis dan MGS untuk deep frying.

Pembelian. Proporsi terbesar frekuensi pembelian oleh responden ialah sebulan sekali $(40,5 \%)$. Sembilan dari empat belas responden $(64,3 \%)$ membeli MGS sebanyak 1-2 liter setiap kali berbelanja. Berdasarkan hasil wawancara, beberapa responden mengaku hanya membeli MGS ketika hendak menggoreng makanan yang membutuhkan minyak berlimpah seperti kentang goreng, nugget, dan sebagainya. Konsumsi makanan sejenis ini tidak terlalu sering karena dipandang kurang menyehatkan. Beberapa responden juga menyatakan hanya menggoreng menjelang momen kebersamaan tertentu seperti hari raya. Hal ini menyebabkan konsumen lebih jarang membeli MGS, tidak sedikit dari responden yang bahkan frekuensi pembeliannya di atas sebulan sekali $(28,6 \%)$.

Penggunaan. Intensitas penggunaan oleh responden didominasi oleh pemakaian di atas seminggu sekali $(42,9 \%)$ dan setiap hari $(30,9 \%)$ sebagai intensitas penggunaan tertinggi kedua. Tingkat pembelian tentu dipengaruhi oleh tingkat konsumsi konsumen. Pemakaian di atas seminggu sekali menyebabkan frekuensi dan jumlah pembelian yang lebih sedikit. Mayoritas responden $(73,8 \%)$ juga menggunakan ulang sisa MGS yang telah digunakan.

Tabel 1 Seberan konsumen responden berdasarkan karakteristik demografi

\begin{tabular}{llrr}
\hline \multicolumn{1}{c}{ Variabel } & \multicolumn{1}{c}{ Kategori } & $\mathrm{N}$ & $\%$ \\
\hline Jenis kelamin & Pria & 6 & 14,3 \\
& Wanita & 36 & 85,7 \\
\hline Usia & Dewasa awal (19-24 & 2 & 4,8 \\
& tahun) & & \\
& Dewasa lanjut (25- & 7 & 16,7 \\
& 35 tahun) & &
\end{tabular}

Paruh baya (36-50 $29 \quad 69$ tahun)

\begin{tabular}{llrr} 
& Tua (51-65 tahun) & 4 & 9,5 \\
\hline Pendidikan & SMA & 8 & 19 \\
& D3 & 7 & 16,7 \\
& S1 & 25 & 59,5 \\
& S3 & 1 & 2,4 \\
& Profesi & 1 & 2,4 \\
\hline Pekerjaan & Pegawai swasta & 5 & 11,9 \\
& Wiraswasta & 5 & 11,9 \\
& lbu rumah tangga & 32 & 76,2 \\
\hline Pendapatan & $<$ Rp10.000.000,00 & 2 & 4,8 \\
& Rp10.000.000,00- & 1 & 2,4 \\
& Rp20.000.000,00 & & \\
& Rp20.000.001,00- & 3 & 7,1 \\
& Rp30.000.000,00 & & \\
& Rp30.000.001,00- & 2 & 4,8 \\
& Rp40.000.000,00 & & \\
& Rp40.000.001,00- & 2 & 4,8 \\
& Rp50.000.000,00 & & \\
& $\geq$ Rp50.000.001,00 & 32 & 76,2 \\
\hline Besar rumah & 2 orang & 3 & 7,1 \\
tangga & 3 orang & 10 & 23,8 \\
& 4 orang & 20 & 47,6 \\
& 5 orang & 7 & 16,7 \\
& 6 orang & 2 & 4,8 \\
\hline Durasi menetap & $\leq 4$ tahun & 4 & 9,5 \\
& 5-10 tahun & 24 & 57,1 \\
& 11-15 tahun & 5 & 11,9 \\
& 16-20 tahun & 7 & 16,7 \\
& $\geq 21$ tahun & 2 & 4,8 \\
\hline Ken & 42 & 100 \\
\hline & Total & &
\end{tabular}

Keterangan: $\mathrm{N}=$ jumlah responden; \%=persentase 
Tabel 2 Sebaran konsumen responden berdasarkan preferensi, pembelian, penggunaan

\begin{tabular}{|c|c|c|c|c|}
\hline Variabel & Dimensi & Kategori & $\mathrm{N}$ & $\%$ \\
\hline \multirow[t]{9}{*}{ Preferensi } & \multirow[t]{2}{*}{ Preferensi minyak goreng } & Hanya menggunakan MGS & 1 & 2,4 \\
\hline & & Menggunakan MGS dan impor & 41 & 97,6 \\
\hline & \multirow[t]{2}{*}{ Prioritas minyak goreng } & MGS & 14 & 33,3 \\
\hline & & Minyak goreng impor & 28 & 66,7 \\
\hline & \multirow[t]{5}{*}{$\begin{array}{l}\text { Alasan konsumsi minyak } \\
\text { goreng impor }\end{array}$} & $\begin{array}{l}\text { Kebiasaan menggunakan minyak } \\
\text { goreng impor }\end{array}$ & 6 & 14,3 \\
\hline & & Persepsi kesehatan & 6 & 14,3 \\
\hline & & Memasak hidangan tertentu & 20 & 47,6 \\
\hline & & Kepercayaan pada merek & 9 & 21,4 \\
\hline & & Hanya menggunakan MGS & 1 & 2,4 \\
\hline \multirow[t]{8}{*}{ Pembelian } & \multirow[t]{5}{*}{ Frekuensi pembelian } & Seminggu sekali & 1 & 2,4 \\
\hline & & Dua minggu sekali & 8 & 19,0 \\
\hline & & Tiga minggu sekali & 6 & 14,3 \\
\hline & & Sebulan sekali & 17 & 40,5 \\
\hline & & >Sebulan sekali & 10 & 23,8 \\
\hline & \multirow[t]{3}{*}{ Kuantitas pembelian } & $<1$ liter & 13 & 30,9 \\
\hline & & 1-2 liter & 27 & 64,3 \\
\hline & & 3-4 liter & 2 & 4,8 \\
\hline \multirow[t]{7}{*}{ Penggunaan } & \multirow[t]{4}{*}{ Intensitas penggunaan } & Setiap hari & 13 & 30,9 \\
\hline & & 2-3 kali seminggu & 5 & 11,9 \\
\hline & & Seminggu sekali & 6 & 14,3 \\
\hline & & >Seminggu sekali & 18 & 42,9 \\
\hline & \multirow[t]{3}{*}{ Penggunaan ulang } & Menggunakan ulang & 31 & 73,8 \\
\hline & & Tidak menggunakan ulang & 11 & 26,2 \\
\hline & & Total & 42 & 100 \\
\hline
\end{tabular}

Keterangan: $\mathrm{N}=$ jumlah responden; \%=persentase

\section{Proses Keputusan Pembelian}

Proses keputusan pembelian konsumen merupakan tahapan-tahapan yang terdiri atas pengenalan kebutuhan, pencarian informasi, evaluasi alternatif, keputusan pembelian, serta perilaku pasca pembelian.

Pengenalan Kebutuhan. Tahap pengenalan kebutuhan pada penelitian ini dianalisis melalui pertanyaan mengenai alasan pembelian serta manfaat yang diinginkan konsumen dari pembelian MGS. Data menunjukkan bahwa mayoritas alasan konsumen membeli MGS dikarenakan harganya. Lebih dari setengah responden menjawab harga yang terjangkau sebagai alasan pembelian $(64,3 \%)$ serta mendapat produk berkualitas dengan harga terjangkau sebagai manfaat yang dicari $(59,5 \%)$.

Pencarian Informasi. Setelah menyadari kebutuhannya, konsumen akan mencari informasi terkait produk. Sebagian besar konsumen $(64,3 \%)$ memperoleh informasi mengenai MGS dari penjual atau toko. Sebagian kecil responden memperoleh informasinya dari teman $(16,7 \%)$, keluarga
$(11,9 \%)$, internet $(4,8 \%)$, dan acara atau pameran $(2,4 \%)$. Kualitas produk menempati posisi paling tinggi sebagai fokus perhatian responden terhadap informasi $(45,2 \%)$, disusul bahan dasar $(31 \%)$, harga $(11,9 \%)$, merek tepercaya $(7,1 \%)$, dan kemudahan diperoleh $(4,8 \%)$.

Evaluasi Alternatif. Informasi yang diperoleh mengenai produk akan digunakan dalam menyusun kriteria-kriteria yang mengeluarkan berbagai evaluasi alternatif. Pada pertanyaan mengenai evaluasi alternatif, responden diharuskan menjawab faktor utama yang dipertimbangkan saat mengevaluasi dan memilih merek-merek MGS. Berdasarkan data, pilihan kualitas menempati posisi pertama $(40,5 \%)$, disusul oleh harga $(33,3 \%)$, bahan dasar $(23,8 \%)$, dan kemasan $(2,4 \%)$.

Keputusan Pembelian. Tahap keputusan pembelian ialah tahap ketika konsumen melakukan pembelian aktual terhadap suatu produk. Lebih dari setengah responden $(52,4 \%)$ melakukan pembelian terencana. Selain itu, hampir setengah responden $(47,6 \%)$ membeli MGS dengan inisiatif sendiri. MGS dijual dalam berbagai bentuk kemasan. Responden membeli 
MGS dalam dua bentuk kemasan yakni plastik $(52,4 \%)$ dan botol $(47,6 \%)$. Merek MGS yang paling banyak dibeli ialah Filma $(35,7 \%)$, disusul oleh Tropical (26,2\%), Bimoli $(23,8 \%)$, dan Sania $(4,8 \%)$. Hasil penelitian juga menemukan sebagian kecil responden $(9,5 \%)$ tidak menentu dalam membeli MGS atau dapat membeli merek apapun.

Perilaku Pasca Pembelian. Tahap ini merupakan tindakan lanjutan konsumen berdasarkan kepuasan terhadap produk. Hasil penelitian menunjukkan hampir seluruh responden merasa puas $(90,5 \%)$ dan berniat membeli MGS kembali $(95,2 \%)$. Dua dari tiga responden bersedia merekomendasikan orang lain untuk membeli MGS. Selanjutnya, jika MGS tidak tersedia, proporsi responden yang akan membeli minyak goreng impor 9,5 kali lipat lebih banyak dari responden yang tidak membeli apapun. Sikap responden apabila harga MGS mengalami kenaikan adalah setengah responden (50\%) tetap membeli, hampir setengahnya $(47,6 \%)$ membeli produk lain yang lebih murah, dan seorang responden $(2,4 \%)$ tidak membeli apapun.

\section{Hubungan Faktor Budaya dan Sosial dengan Proses Keputusan Pembelian}

Proses keputusan pembelian konsumen berkaitan dengan beberapa faktor utama seperti faktor budaya dan sosial. Korelasi faktor budaya dan sosial dengan keputusan pembelian MGS warga Korea dapat dilihat melalui Tabel 3.

Hasil penelitian menunjukkan faktor budaya berhubungan signifikan, positif dan kuat dengan proses keputusan pembelian $(r=0,609, p<0,01)$. Hasil ini menunjukkan semakin kuat faktor budaya, semakin kuat juga keputusan konsumen untuk melakukan pembelian. Hasil analisis juga menemukan bahwa faktor sosial berhubungan signifikan, positif, dan rendah dengan proses keputusan pembelian $(r=0,319$, $p<0,01$ ). Semakin tinggi faktor sosial, semakin tinggi juga keputusan konsumen untuk melakukan pembelian.

Tabel 3 Koefisien korelasi antara faktor budaya dan sosial dengan keputusan pembelian

Variabel Keputusan pembelian $(r)$

\begin{tabular}{ll}
\hline Faktor budaya & $0,609^{\star \star}$ \\
\hline Faktor sosial & $0,319^{\star \star}$ \\
\hline
\end{tabular}

Keterangan: **Signifikan pada $\mathrm{p}<0,01$

\section{PEMBAHASAN}

Persepsi kualitas konsumen lebih baik pada minyak goreng impor dibandingkan MGS. Minyak goreng impor yang diproduksi di luar negeri menghasilkan persepsi kualitas yang lebih unggul sehingga mayoritas responden tidak hanya menggunakan MGS tetapi juga menggunakan minyak goreng impor bahkan memprioritaskannya. Hasil ini didukung oleh penelitian Listiana (2012) yang menunjukkan, country of origin (negara asal) memengaruhi persepsi kualitas konsumen secara signifikan. Negara asal merupakan unsur ekstrinsik yang memengaruhi persepsi konsumen dalam mengevaluasi produk, yang kemudian memengaruhi preferensi, niat pembelian serta pilihan merek. Penelitian Rochaeni (2013) juga menunjukkan mayoritas konsumen lebih menyukai buah impor karena dinilai lebih unggul dalam penampilan, aksesibilitas, harga, dan prestige.

Selain persepsi kualitas, perbedaan utilitas antara MGS dan impor menjadi alasan utama responden untuk tetap menggunakan minyak goreng impor. Seperti yang diketahui, MGS berbahan dasar minyak sawit sementara mayoritas minyak goreng impor berbahan dasar bukan sawit seperti zaitun, jagung, kedelai, dan sebagainya. Masing-masing minyak memiliki karakteristiknya tersendiri dan digunakan dalam keadaan yang berbeda. Pada penggunaan untuk pan frying atau tumis, minyak hanya digunakan sekali dalam jumlah sedikit sehingga dapat menggunakan minyak goreng seperti salad oil dalam bentuk minyak kedelai, jagung, dan zaitun. Sementara itu, penggunaan untuk deep frying dengan minyak berlimpah dan dipakai beberapa kali harus menggunakan minyak yang tahan panas seperti minyak kelapa sawit dan kelapa (Budijanto \& Sitanggang, 2016).

Sikap responden yang memprioritaskan minyak goreng impor memengaruhi tingkat konsumsi dan pembelian MGS. Hasil penelitian menemukan bahwa frekuensi pembelian MGS mayoritas responden hanya sekali dalam sebulan, lebih rendah dibandingkan WNI. Penelitian Anggraeni dan Adiwijaya (2017) menunjukkan bahwa mayoritas frekuensi pembelian minyak goreng Letiza pada WNI ialah dua kali dalam sebulan. Selain frekuensi pembelian, kuantitas pembelian mayoritas responden juga lebih rendah dibandingkan WNI. Penelitian Qorima, Prasmatiwi, dan Adawiyah (2014) menunjukkan mayoritas responden membeli minyak goreng kemasan 
sebanyak 4 liter, dua kali lebih banyak daripada responden Korea. Penelitian Sandjaja, Sudikno, dan Jus'at (2015) menunjukkan mayoritas responden membeli dalam jumlah kecil namun lebih sering yakni 250 mililiter tiga hari sekali, atau sekitar 2,5 liter dalam sebulan. Frekuensi dan kuantitas pembelian yang rendah disebabkan oleh intensitas penggunaan yang rendah juga. Hasil menemukan bahwa responden menggunakan MGS di atas seminggu sekali. MGS hanya digunakan untuk deep frying dengan minyak berlimpah yang dipandang kurang menyehatkan. Hal ini membuat konsumsi MGS responden menjadi rendah. Berbeda halnya dengan penelitian Amalia, Retnaningsih, dan Johan (2010) yang menunjukkan mayoritas responden menggunakan minyak goreng setiap hari.

Konsumen mengenali masalah atau kebutuhannya dalam tahap pengenalan kebutuhan. Kebutuhan konsumen Korea ialah mendapatkan minyak goreng dengan harga terjangkau untuk melakukan proses deep frying yang membutuhkan minyak berlimpah. Harga menjadi faktor utama dalam tahap ini karena konsumen membandingkan MGS dengan minyak goreng impor yang biasa digunakan. Selain harganya yang mahal, mayoritas merek minyak goreng impor yang beredar juga kurang cocok untuk deep frying karena tidak tahan panas. Maka dari itu, produk MGS dengan harga yang murah dan tahan panas menjadi alternatif bagi konsumen Korea. Hal serupa juga terjadi dalam penelitian Bukhori dan Ekasari (2017) serta Delima dan Nasution (2020) yang menunjukkan bahwa harga merupakan alasan pembelian minyak goreng curah dan Bimoli.

Tempat penjualan menjadi sumber informasi utama mengenai MGS bagi responden. Hal ini juga terjadi pada penelitian Delima dan Nasution (2020) yang mana keseluruhan responden memperoleh informasi dari penjual serta penelitian Qorima et al. (2014) yang menyatakan mayoritas sumber informasi konsumen ialah tempat pembelian seperti supermarket. Fokus perhatian dari informasi sebagian besar konsumen ialah kualitas produk. Setelah konsumen mengenal bahwa produk MGS sesuai dengan kebutuhannya sebagai produk yang murah dan tahan panas, konsumen selanjutnya membutuhkan informasi tambahan mengenai kualitas dari merek-merek MGS. Informasi tersebut akan digunakan konsumen dalam mengevaluasi dan memutuskan merek yang akan dibelinya pada tahap evaluasi alternatif dan keputusan pembelian. Jenis informasi yang difokuskan ialah kualitas mengingat mayoritas konsumen berusia paruh baya sehingga penting untuk memperoleh merek MGS yang berkualitas. Penelitian oleh Dwinada (2012) juga menunjukkan mayoritas responden menjadikan kualitas produk sebagai fokus informasi.

Bentuk kemasan dapat memengaruhi keputusan pembelian suatu produk. Mayoritas konsumen membeli MGS dalam kemasan plastik. Di Korea minyak goreng biasanya hanya dijual dalam bentuk botol, sehingga kemasan plastik menjadi hal yang baru bagi konsumen Korea. Kemasan plastik merupakan konsep kemasan isi ulang, ekonomis, dan praktis sehingga memudahkan pemakaian. Hal ini juga terjadi pada penelitian Dwinada (2012) dan penelitian Sundari et al. (2018) yang menunjukkan mayoritas responden membeli kemasan plastik. Merek yang paling banyak dibeli ialah Filma. Filma memang termasuk dalam 5 besar merek minyak goreng kemasan ternama di Indonesia. Pada fase pertama tahun 2020, Filma menempati posisi kedua setelah Bimoli dengan Top Brand Index 13,9 persen (Top Brand Award, 2020). Minyak goreng Filma dibuat dari 100 persen bahan nabati dan dikenal dengan kandungannya yang bebas kolesterol dan kaya akan nutrisi karena mengandung Vitamin $D$, Omega-6, dan Omega-9. Hal ini yang menyebabkan mayoritas responden memilih Filma sebagai merek yang dibelinya. Penelitian Karosekali dan Natasha (2018) juga menunjukkan mayoritas konsumen membeli Filma untuk menunjang gaya hidup sehat.

Harapan dan kenyataan yang dialami konsumen terkait kinerja MGS sudah sesuai. Hal ini ditunjukkan dengan tercapainya kepuasan serta niat pembelian ulang dari mayoritas responden. Ketika suatu produk berhasil memuaskan konsumen dalam memenuhi kebutuhan dan keinginannya, pembelian ulang terhadap produk tersebut pasti akan terjadi (Ekaprana, Jatra, \& Giantari, 2020). Hasil ini sejalan dengan penelitian Dwinada (2012) yang menunjukkan hampir semua responden puas dan berniat membeli Bimoli kembali. Kepuasan konsumen juga akan mendorong konsumen untuk merekomendasikan produk kepada orang lain.

Hasil analisis menunjukkan bahwa semakin tinggi faktor budaya, proses keputusan pembelian konsumen juga semakin tinggi. Hal ini berarti jika suatu produk semakin mendukung kebiasaan, sikap, budaya serba cepat, etnosentrisme, serta nilai sosial konsumen maka konsumen akan semakin 
mantap dalam memutuskan, mencari informasi, membeli, merekomendasikan, dan membeli produk tersebut kembali. Tingkat hubungan yang kuat dikarenakan budaya merupakan penyebab dasar keinginan dan perilaku konsumen. Persepsi, pola pikir, dan tindakan konsumen dalam memutuskan pembelian ditentukan oleh lingkungan budaya sekitarnya (Kotler \& Keller, 2016). Norma budaya dilandaskan pada nilai, kepercayaan, dan sikap yang ditetapkan dengan kuat oleh suatu kelompok masyarakat. Budaya berpengaruh terhadap perilaku pembelian sebab ia terserap ke dalam aktivitas sehari-hari. Budaya menentukan hal yang seorang dengar, santap, tempati, dan tuju sehingga budaya sangat memengaruhi kebiasaan seseorang.

Makanan Korea adalah masakan khas yang merupakan hasil dari perkembangan budaya, geografi, lingkungan, dan iklim negara Korea sendiri. Makanan-makanan Korea dikenal sehat karena bahan dasar utamanya merupakan sayuran. Mayoritas makanan Korea merupakan hasil fermentasi. Fermentasi digunakan orang Korea turun-temurun karena dipercaya bermanfaat bagi kesehatan. Tujuan fermentasi ialah memecahkan komponen makanan melalui bakteri alami sehingga lebih mudah dicerna. Mayoritas makanan Korea yang difermentasi sudah terkenal dan diakui manfaat kesehatannya, misalnya kimchi. Kimchi adalah fermentasi sayuran yang selalu dihidangkan dalam menu sehari-hari orang Korea dan termasuk dalam jajaran lima makanan tersehat di dunia (Masbudi, Yuwono, \& Kurniawan, 2014).

Selain fermentasi, teknik merebus juga biasa dilakukan orang Korea sejak lama. Makanan Korea biasanya tidak digoreng tetapi direbus, dikukus atau difermentasi (Henny, Rochayanti, \& Isbandi, 2011). Selain itu, orang Korea juga menghindari makanan yang terlalu berminyak karena dipandang kurang menyehatkan. Hal ini menyebabkan kandungan minyak pada makanan Korea jauh lebih sedikit dibandingkan dengan mayoritas makanan nusantara yang digoreng (Rencidiptya \& Hasanah, 2020). Kebiasaan tersebut tentu berkaitan erat dengan pembelian dan konsumsi MGS. MGS yang digunakan untuk menggoreng dengan proses deep frying tentu lebih jarang digunakan oleh konsumen Korea karena ingin mengurangi konsumsi makanan dengan kandungan minyak yang besar.

Selain budaya makan, budaya yang berlaku secara fundamental bagi masyarakat Korea ialah budaya serba cepat yang dikenal dengan istilah budaya ppalli-ppalli (빨리 빨리). Ppallippalli merupakan kata dari Bahasa Korea yang berarti cepat atau tergesa-gesa. Gaya hidup serba cepat tersebut mendorong kebutuhan akan produk yang mudah disajikan dengan cepat dan mudah diperoleh. Maka, kosumen membeli MGS untuk dipakai menggoreng yang dipandang praktis dan tersedia di banyak tempat. Menggoreng merupakan salah satu teknik pengolahan makanan tertua yang populer dikarenakan kemudahan dan kecepatannya serta menghasilkan rasa yang unik (Bordin et al., 2013).

Nilai kebudayaan lain yang berhubungan dengan proses keputusan konsumen ialah etnosentrisme, yakni keputusan konsumen untuk lebih memilih produk buatan negerinya dan menolak produk luar (Sukmaningtyas \& Hartoyo, 2013). Orang Korea dikenal dengan semangat patriotismenya yang tinggi. Rasa identitas nasional dan penghargaan terhadap kedaulatan nasional menjadi tujuan utama pendidikan di Korea. Tujuan tersebut dicapai salah satunya melalui penanaman sikap patriotisme (Suastika, 2021). Nilai patriotisme warga Korea dapat dicerminkan melalui perilakunya sebagai konsumen yang cenderung memilih produk buatan negerinya. Hal ini sejalan dengan hasil penelitian yang menunjukkan merek minyak goreng yang paling sering digunakan konsumen ialah yang berasal dari Korea. Selain patriotisme, warga Korea juga dididik untuk memiliki nilai sosial seperti rasa tanggung jawab dan solidaritas terhadap komunitas tempat ia tinggal (Suastika, 2021). Nilai tersebut dicerminkan melalui sikap konsumen yang tidak tertutup untuk mencoba MGS buatan Indonesia.

Hasil analisis juga menunjukkan semakin tinggi faktor sosial, proses keputusan pembelian konsumen akan semakin tinggi, tetapi tingkat hubungannya tidak sekuat faktor budaya. Pentingnya faktor sosial berupa kelompok acuan akan berbeda tergantung pada jenis produk serta merek. Kelompok cenderung berpengaruh kuat untuk produk yang terlihat oleh orang lain yang dihargai konsumen. Produk-produk untuk kepentingan pribadi tidak terlalu terpengaruh kelompok (Kotler \& Keller, 2016). Hal ini terjadi pada produk MGS. Produk tersebut termasuk kebutuhan pokok yang digunakan untuk memenuhi kebutuhan seharihari. Keputusan pembelian konsumen didasarkan pada kebutuhan dan kemampuannya sehingga hubungan pengaruh kelompok tidak terlalu kuat untuk produk MGS. 
Penelitian Magdalena, Kusumawaty, dan Maharani (2019), serta penelitian Kusumawaty, Edwina, dan Sifqiani (2019) juga menunjukkan bahwa mayoritas pembelian minyak goreng kemasan oleh responden lebih dipengaruhi oleh diri konsumen sendiri dibandingkan referen sekitar. Pengaruh utama terletak pada diri sendiri, bukan teman atau keluarga.

Seorang individu merupakan bagian dari kelompok-kelompok. Posisi individu tersebut pada setiap kelompok dapat didefinisikan melalui peran dan statusnya (Kotler \& Keller, 2016). Pada kelompok keluarga, mayoritas konsumen berperan sebagai ibu rumah tangga yang memiliki peran besar untuk bertanggung jawab dalam mengatur konsumsi rumah tangga. Konsumen berperan khususnya terkait pemilihan bahan-bahan makanan yang baik bagi kesehatan serta mengatur pengeluaran terhadap bahan-bahan makanan tersebut. Saat pembelian MGS, peran yang dijalankan konsumen terkait dengan pengeluarannya. Produk MGS dipandang murah sehingga dapat mengurangi pengeluaran konsumen terhadap bahan makanan. MGS kurang dipandang sebagai produk yang bermanfaat bagi kesehatan sehingga pembelian produk tersebut kurang mendukung peran konsumen terkait pemilihan bahan-bahan makanan yang baik bagi kesehatan keluarga.

\section{SIMPULAN DAN SARAN}

Konsumen MGS didominasi oleh ibu rumah tangga, sarjana, berpendapatan Rp50.000.000,00 per bulan, dan menggunakan dua jenis minyak goreng (sawit dan impor) dengan minyak impor sebagai prioritasnya. Hal ini dikarenakan persepsi kualitas konsumen yang lebih baik pada minyak impor sehingga frekuensi dan kuantitas pembelian MGS menjadi lebih rendah dibandingkan dengan konsumen Indonesia yakni sebulan sekali sebanyak 1-2 liter serta digunakan di atas seminggu sekali. Manfaat yang diinginkan konsumen dalam pengenalan kebutuhan ialah mendapatkan minyak goreng dengan harga terjangkau dan kualitas yang baik untuk melakukan proses deep frying yang membutuhkan minyak berlimpah. Harga menjadi faktor utama pada tahap ini karena konsumen membandingkan MGS dengan minyak goreng impor yang biasa digunakan. Kemudian, konsumen mencari informasi mengenai kualitas dari berbagai merek di pasaran. Selanjutnya, konsumen akan melakukan evaluasi dengan membandingkan merek-merek tersebut berdasarkan kualitasnya. Mayoritas pola pembelian konsumen direncanakan dengan inisiatif sendiri. Merek yang paling banyak dibeli ialah Filma. Konsumen merasa puas dan berniat untuk membeli MGS kembali. Hasil analisis menunjukkan bahwa faktor budaya memiliki hubungan yang signifikan, positif, dan kuat dengan keputusan pembelian MGS sementara faktor sosial memiliki hubungan yang signifikan, positif, dan rendah. Hal ini dikarenakan budaya yang didasarkan oleh nilai-nilai, keyakinan, dan sikap sangat memengaruhi persepsi dan kebiasaan konsumen, sedangkan pengaruh sosial tidak terlalu besar pada produk kebutuhan pokok atau pribadi seperti minyak goreng. Budaya makan orang Korea yang sangat sehat dengan kebiasaan menghindari konsumsi minyak berlebih menyebabkan konsumsi MGS yang rendah.

Hasil penelitian ini dapat digunakan sebagai informasi mengenai perilaku konsumen Korea khususnya dalam keputusan pembelian MGS. Penelitian ini menyarankan perlu adanya peningkatan pengetahuan konsumen Korea terkait kualitas MGS mulai dari rasa, warna, bau, kejernihan, dan ketahanan. Edukasi melalui iklan atau kampanye yang memperlihatkan bahwa produk MGS baik bagi kesehatan patut dijadikan prioritas. Hasil penelitian menunjukkan bahwa mayoritas responden memperoleh informasinya dari toko. Oleh karena itu, upaya edukasi atau pemasaran lebih baik dilakukan langsung di tempat penjualan. Penyediaan tester hasil olahan beserta demonstrasi masak yang langsung dilakukan di tempat penjualan juga dapat dilakukan guna meningkatkan pengetahuan, persepsi, pengalaman, dan kepercayaan konsumen. Selain untuk deep frying, konsumen disarankan untuk menggunakan MGS juga saat menumis. Penelitian ini tidak luput dari beberapa keterbatasan. Penelitian terbatas pada konsumen Korea yang tidak dapat menggambarkan perilaku konsumen WNA lainnya. Teknik pengambilan sampel yang digunakan berupa snowball sampling dikhawatirkan dapat membuat data hasil penelitian kurang merepresentasikan populasi. Selain itu, fokus bahasan mengenai faktor pengaruh hanya pada faktor budaya dan sosial dengan alat analisis yang sederhana. Penelitian selanjutnya disarankan untuk menggunakan teknik analisis yang lebih kompleks seperti analisis regresi berganda serta mengumpulkan data yang berjumlah lebih besar, beragam, dan secara acak untuk memperoleh hasil yang lebih maksimal. Penelitian mengenai sub-topik lainnya seperti preferensi atau sikap konsumen dengan faktor pengaruh lainnya juga dapat 
dilakukan guna memperoleh lebih banyak informasi mengenai perilaku konsumen WNA baik untuk komoditas minyak goreng ataupun komoditas lainnya.

\section{DAFTAR PUSTAKA}

Amalia, F., Retnaningsih, \& Johan, I. R. (2010). Perilaku penggunaan minyak goreng serta pengaruhnya terhadap keikutsertaan program pengumpulan minyak jelantah di Kota Bogor. Jurnal IImu Keluarga \& Konsumen, 3(2), 184-189. doi:10.24156/jikk.2010.3.2.184.

Anggraeni, F., \& Adiwijaya, M. (2017). Analisis pengaruh marketing mix terhadap keputusan pembelian minyak goreng Letizia di Pandaan. Agora, 5(1), 15-22.

Asprilia, M. T., \& Hami, A. E. (2021). Persepsi nilai mewah pada konsumen tas branded: Kajian nilai budaya di Indonesia. Jurnal Ilmu Keluarga \& Konsumen, 14(1), 76-87. doi:10.24156/jikk.2021.14.1.76.

Bordin, K., Kunitake, M. T., Aracava, K. K., \& Trindade, C. S. F. (2013). Changes in food caused by deep fat frying-a review. Archivos latinoamericanos de nutricion, 63(1), 5-13.

[BPS] Badan Pusat Statistik. (2019). Pengeluaran untuk Konsumsi Penduduk Indonesia per Provinsi. Retrieved from https://www.bps.go.id/publication/2019/06/ 28/c27c8e5d87315a29c3f76b8a/pengeluar an-untuk-konsumsi-penduduk-indonesiaper-provinsi-september-2018.html.

Budijanto, S., \& Sitanggang, A. B. (2016). Kajian keamanan pangan dan kesehatan minyak goreng. Jurnal Pangan, 19(4), 361372. doi:10.33964/jp.v19i4.165.

Budiman, S. (1997). Pengaruh faktor kebudayaan terhadap keputusan pembelian oleh konsumen. Bina Ekonomi, 1(1), 36-42.

Bukhori, M., \& Ekasari, T. (2017). Faktor-faktor yang dipertimbangkan dalam keputusan pembelian minyak goreng Bimoli pada ibu rumah tangga Desa Kebonagung Kecamatan Purworejo Kota Pasuruan. Jurnal IImiah Bisnis dan Ekonomi Asia, 11(2), 11-19. doi:10.32812/jibeka.v11i2.40.

Delima, S., \& Nasution, M. P. (2020). Analisis faktor yang mempengaruhi konsumen dalam pengambilan keputusan pembelian minyak goreng curah. Agriprimatech, 4(1), 1-6. doi:10.34012/agriprimatech.v4i1.1219.

Dwinada, F. (2012). Analisis faktor-faktor keputusan pembelian minyak goreng kemasan merek Bimoli (Studi kasus: Rumah tangga di Kota Bogor) (Thesis). Bogor, ID: Institut Pertanian Bogor.

Ekaprana, I. D. G. A., Jatra, I. M., \& Giantari, I. G. A. K. (2020). Pengaruh kualitas produk, kualitas layanan dan citra merek terhadap niat pembelian ulang. E-Jurnal Manajemen, 9(8), 2895-2914. doi:10.24843/EJMUNUD.2020.v09.i08.p01

Haryono, H. (2017). Globalisasi dan migrasi tenaga kerja Indonesia: Studi deskriptif sosiologi kependudukan. Hermeneutika: Jurnal Hermeneutika, 3(2), 1-13. doi:10.30870/hermeneutika.v3i2.3084.

Henny, Z., Rochayanti, C., \& Isbandi, I. (2011). Komunikasi antarbudaya mahasiswa Korea Selatan di Yogyakarta. Jurnal IImu Komunikasi Terakreditasi, 9(1), 40-48.

Jimanto, R. B. (2014). Pengaruh service quality terhadap loyalitas pelanggan dengan customer satisfaction sebagai variabel intervening pada ritel bioskop The Premiere Surabaya. Jurnal Strategi Pemasaran, 2(1), 1-7.

Karosekali, A. S., \& Natasha, N. (2018). Analisis faktor-faktor keputusan pembelian konsumen minyak goreng pada merek Filma (Studi kasus: Brastagi Supermarket Cabang Gatot Subroto Medan). Agriprimatech, 2(1), 29-39.

Kartika, A., \& Ningsih, T. (2017). Analisis pengaruh faktor marketing mix terhadap keputusan pembelian minyak goreng kemasan di Pasar Tradisional Sukaramai Medan. Jurnal Agro Estate, 1(1), 62-72. doi:10.47199/jae.v1i1.62.

Kementerian Pertanian. (2019). Buletin konsumsi pangan. Retrieved from http://epublikasi.setjen.pertanian.go.id/dow nload/file/519-buletin-konsumsi-pangans2-2019.

Kotler, P., \& Keller, K. L. (2016). Marketing Management: Global Edition (15th ed.). New Jersey, NJ: Pearson.

Kumar, M. S. (2014). Brand preference and buying decision: A study with reference to organized Indian edible oil brands. African Journal of Marketing Management, 6(2), 17-26. doi:10.5897/AJMM2013.0353. 
Kusumawaty, Y., Edwina, S., \& Sifqiani, N. S. (2019). Sikap dan perilaku konsumen minyak goreng curah dan kemasan di Kota Pekanbaru. Jurnal Ecodemica: Jurnal Ekonomi, Manajemen, dan Bisnis, 3(2), 111-122. doi:10.31294/jeco.v3i2.5476.

Listiana, E. (2012). Pengaruh country of origin terhadap perceived quality dengan moderasi etnosentris konsumen. Jurnal Administrasi Bisnis, 8(1), 21-47.

Magdalena, S., Kusumawaty, Y., \& Maharani, E. (2019). Sikap dan perilaku belanja konsumen minyak goreng kemasan di Kecamatan Pangkalan Kerinci Kabupaten Pelalawan. Jurnal Agribisnis, 21(1), 36-48. doi:10.31849/agr.v21i1.2570.

Masbudi, M., Yuwono, E. C., \& Kurniawan, A. S. (2014). Perancangan buku pengenalan makanan khas Korea. Jurnal DKV Adiwarna, 1(4), 1-13.

Nasution, M. P., \& Syuhada, M. F. (2018). Pengaruh pendapatan, harga dan merek (Bimoli dan Filma) terhadap jumlah minyak goreng yang dibeli. Agriprimatech, 2(1), 19-28.

Newsroom Diskominfosantik. (2020). Bekasi: Ada 5.174 WNA tinggal di Kabupaten Bekasi. Retrieved from http://bekasikab.go.id/berita/2322/kantorimigrasi-bekasi--ada-5174-wna-tinggal-dikabupaten-bekasi.

Pasaribu, R. F. A., Kakana, L. A., Hutahuruk, T. E., \& Hutasoit, E. A. (2019). Pengaruh harga dan promosi terhadap keputusan pembelian minyak goreng Bimoli pada PT. Salim Ivomas Pratama, Tbk Lubuk Pakam. Jurnal IImiah Socio Secretum, 9(1), 183194.

Pinem, L. J., \& Safrida. (2018). Analisis faktorfaktor keputusan pembelian minyak goreng Bimoli di Kecamatan Kota Pinang, Kab. Labuhanbatu Selatan. Agriprimatech, 1(2), 33-38.

Qorima, R. N., Prasmatiwi, F. E., \& Adawiyah, R. (2014). Tingkat kepuasan dan loyalitas ibu rumah tangga dalam mengonsumsi minyak goreng kemasan di Kota Bandar Lampung. Journal of Agribusiness Science, 2(3), 285-294. doi:10.23960/jiia.v2i3.285-294.

Ramya, N., \& Ali, S. M. (2016). Factors affecting consumer buying behavior. International Journal of Applied Research, 2(10), 76-80.
Rencidiptya, T. A., \& Hasanah, U. (2020). Daya tarik menjamurnya restoran Korea di Yogyakarta. Jurnal Sosiologi Reflektif, 14(2),

doi:10.14421/jsr.v14i2.1762.

Rochaeni, S. (2013). Analisis persepsi, kesadaran, dan preferensi konsumen terhadap buah lokal. Agribusiness Journal, 7(1), 91-104. doi:10.15408/aj.v7i1.5172.

Sandjaja, Sudikno, S., \& Jus'at, I. (2015). Konsumsi minyak goreng dan vitamin A pada beberapa kelompok umur di dua kabupaten. Nutrition and Food Research, $38(1)$, 1-10. doi:10.22435/pgm.v38i1.4415.1-10.

Sidjabat, F. M., \& Runtuk, J. K. (2019). Pengembangan model pemilihan green supplier di kawasan industri Cikarang. Journal of Environmental Engineering and Waste Management, 4(1), 9-20. doi:10.33021/jenv.v4i1.659.

Sormin, D. W., \& Waluyo, T. J. (2018). Pengaruh investasi Korea Selatan melalui PT. Hankook Tire Indonesia terhadap perekonomian masyarakat Jawa Barat. Jurnal Online Mahasiswa Fakultas IImu Sosial dan IImu Politik Universitas Riau, 5(1), 1-12.

Suastika, I. N. (2021). Analisis komparasi social studies di China dan Korea Selatan. Jurnal Pendidikan Undiksha, 9(1), 60-69.

Kewarganegaraan

Sukmaningtyas, A., \& Hartoyo. (2013). Pengaruh nilai dan gaya hidup terhadap preferensi dan perilaku pembelian buahbuahan impor. Jurnal IImu Keluarga \& Konsumen, 6(1), 39-48. doi:10.24156/jikk.2013.6.1.39.

Sundari, Y., Harisudin, M., \& Agustono. (2018). Analisis faktor-faktor yang dipertimbangkan konsumen dalam keputusan pembelian minyak goreng bimoli di pasar swalayan Kabupaten Wonogiri. SEPA: Jurnal Sosial Ekonomi Pertanian dan Agribisnis, 15(1), 39-49. doi:10.20961/sepa.v15i1.25048.

Top Brand Award. (2020). Top Brand Index Fase 12020. Retrieved from www.topbrand-award.com/top-brandindex/.

Topcu, Y., Turhan, B., \& Uzundumlu, A. S. (2010). Analysis of factors affecting Turkish sunflower oil consumer behavior: The case of Erzurum province. Italian Journal of Food Science, 22(2). 
Jur. IIm. Kel. \& Kons.

Veterinawati, D. (2013). Pengaruh faktor sosial, pribadi, dan psikologis terhadap keputusan pembelian Blackberry di Surabaya. Jurnal IImu Manajemen, 1(3), 746-759.

Yakup, D., Mucahit, C., \& Reyhan, O. (2011). The impact of cultural factors on the consumer buying behaviors examined through an impirical study. International Journal of Business and Social Science, 2(5), $109-114$

doi:10.24297/ 